\title{
Die Neue Bestreitung der Schweizerischen Entwicklungszusammenarbeit
}

La nouvelle contestation de la coopération suisse au développement

Jacques Forster

\section{OpenEdition}

1 Journals

Édition électronique

URL : http://journals.openedition.org/sjep/939

DOI : $10.4000 /$ sjep.939

ISSN : 1663-9677

Éditeur

Institut de hautes études internationales et du développement

\section{Édition imprimée}

Date de publication : 1 janvier 1981

Pagination : 213-222

ISSN : 1660-5926

\section{Référence électronique}

Jacques Forster, «Die Neue Bestreitung der Schweizerischen Entwicklungszusammenarbeit »,

Schweizerisches Jahrbuch für Entwicklungspolitik [En ligne], 1 | 1981, mis en ligne le 23 janvier 2013

consulté le 08 septembre 2020. URL : http://journals.openedition.org/sjep/939 ; DOI : https://doi.org/ $10.4000 /$ sjep.939

Ce document a été généré automatiquement le 8 septembre 2020

(c) The Graduate Institute 


\title{
Die Neue Bestreitung der Schweizerischen
}

\section{Entwicklungszusammenarbeit}

La nouvelle contestation de la coopération suisse au développement

\author{
Jacques Forster
}

\section{NOTE DE L'ÉDITEUR}

Zusammenfassung auf Deutsch. Volltext auf Französisch in Annuaire suisse de politique de développement: „La nouvelle contestation de la coopération suisse au développement”, http://aspd.revues.org/1092.

\section{RÉSUMÉS}

Seit dem Herbst 1980 sieht sich die DEH (Direktion für Entwicklungszusammenarbeit und humanitäre Hilfe) einer neuen Art von Kritiken ausgesetzt. Sie kommt aus politischen und beruflichen Kreisen, welche sich bisher zu diesem Teil der Regierungspolitik kaum öffentlich äusserten. Seit mehreren Monaten konzentrieren sich diese Kritiken auf die geplante N.O. (Neue Organisation).

Eine genaue Analyse zeigt jedoch, dass sie darüber hinaus wesentliche Aspekte der schweizerischen Entwicklungspolitik angreifen. Die hauptsächlichsten Kritiken betreffen die Verwaltung der Entwicklungszusammenarbeit, ihre Transparenz und ihre Zusammenarbeit mit der Privatwirtschaff.

Die Forderung, die Privatwirtschaft mehr an der Durchführung der 
Entwicklungszusammenarbeit zu beteiligen, erhalt von zwei Seiten Auftrieb. International gesehen erleben wir einen Aufschwung der liberalen Wirtschaftsdoktrin. In der Schweiz selber stehen wachsende Kredite für die Entwicklungszusammenarbeit zur Verfügung. Es stellt sich erneut die Frage, welchen Platz die schweizerische Entwicklungszusammenarbeit in unserer Aussenpolitik einnehmen soll. 